\title{
The Influence of Average Temperature and Relative Humidity on New Cases of COVID-19: Time-Series Analysis
}

Zonglin $\mathrm{He}^{1,2^{*}}$, MBBS; Yiqiao Chin ${ }^{2 *}$, MBBS; Shinning Yu², MBBS; Jian Huang ${ }^{3}$, MPH, PhD; Casper J P Zhang ${ }^{4}$, MPH, PhD; Ke Zhu' ${ }^{1}$, MBBS; Nima Azarakhsh ${ }^{5}$, PhD; Jie Sheng ${ }^{6}$, BA, MSc; Yi He ${ }^{7}$, BA, MSc; Pallavi Jayavanth", $\mathrm{PhD}$; Qian $\mathrm{Liu}^{8}, \mathrm{PhD}$; Babatunde O Akinwunmi ${ }^{9}$, MD, MPH, MMSc, FWACS; Wai-Kit Ming ${ }^{1}$, MD, MPH, PhD, MMSc, EMBA

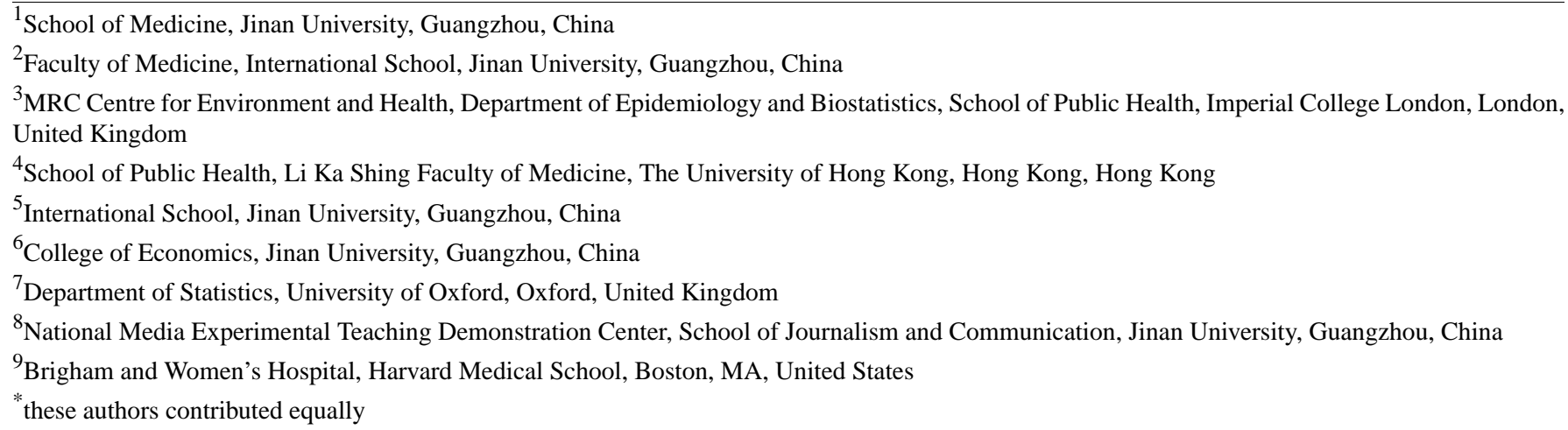

\section{Corresponding Author:}

Wai-Kit Ming, MD, MPH, PhD, MMSc, EMBA

School of Medicine

Jinan University

601 West Huangpu Avenue

Guangzhou

China

Phone: 8614715485116

Email:wkming@connect.hku.hk

\section{Abstract}

Background: The influence of meteorological factors on the transmission and spread of COVID-19 is of interest and has not been investigated.

Objective: This study aimed to investigate the associations between meteorological factors and the daily number of new cases of COVID-19 in 9 Asian cities.

Methods: Pearson correlation and generalized additive modeling (GAM) were performed to assess the relationships between daily new COVID-19 cases and meteorological factors (daily average temperature and relative humidity) with the most updated data currently available.

Results: The Pearson correlation showed that daily new confirmed cases of COVID-19 were more correlated with the average temperature than with relative humidity. Daily new confirmed cases were negatively correlated with the average temperature in Beijing $(r=-0.565, P<.001)$, Shanghai $(r=-0.47, P<.001)$, and Guangzhou $(r=-0.53, P<.001)$. In Japan, however, a positive correlation was observed $(r=0.416, P<.001)$. In most of the cities (Shanghai, Guangzhou, Hong Kong, Seoul, Tokyo, and Kuala Lumpur), GAM analysis showed the number of daily new confirmed cases to be positively associated with both average temperature and relative humidity, especially using lagged 3D modeling where the positive influence of temperature on daily new confirmed cases was discerned in 5 cities (exceptions: Beijing, Wuhan, Korea, and Malaysia). Moreover, the sensitivity analysis showed, by incorporating the city grade and public health measures into the model, that higher temperatures can increase daily new case numbers (beta=0.073, $\mathrm{Z}=11.594, P<.001$ ) in the lagged 3-day model. 
Conclusions: The findings suggest that increased temperature yield increases in daily new cases of COVID-19. Hence, large-scale public health measures and expanded regional research are still required until a vaccine becomes widely available and herd immunity is established.

(JMIR Public Health Surveill 2021;7(1):e20495) doi: 10.2196/20495

\section{KEYWORDS}

COVID-19; coronavirus; meteorological factors; temperature; humidity; weather; transmission; virus; Asia; time-series; analysis; public health

\section{Introduction}

In December 2019, several cases of pneumonia of unknown etiology were reported in Wuhan, Hubei Province, China [1]. A novel strain of coronavirus was identified from the nasopharyngeal swab specimens of infected patients, which was later named SARS-CoV-2, which results in the disease COVID-19. As the number of infectees increased, the World Health Organization declared the outbreak as a public health emergency of international concern on January 31, 2020 [2].

SARS-CoV-2, of the Coronaviridae family, is an enveloped, single-stranded, positive-sense RNA (ribonucleic acid) virus, which is closely related to the SARS (severe acute respiratory syndrome)-like coronaviruses, and based on the phylogenetic analysis, these coronaviruses have a common ancestor that resembles the bat coronavirus HKU9-1 [3,4]. Evidence has shown that SARS-CoV-2 can transmit from person to person via respiratory droplets, fecal-oral route, direct contact, and aerosols [5-7]. Moreover, the long incubation period (1-14 days) increases the difficulty of controlling the COVID-19 outbreak. Studies have shown the mean incubation period to be 5.1 days (range: 2.2-11.5 days, 95\% CI 4.5-5.8) [8]; one study estimated the mean incubation period to be 6.4 days (range: $2-14$ days) [9]. By early July 2020, 215 countries and regions had reported high infection rates, with over 7,000,000 confirmed cases, 400,000 deaths, and a fatality rate of over $5.84 \%$ worldwide [10].

Human respiratory pathogens (bacterial pathogens like pneumococcus and viruses like rubella and influenza) usually exhibit an annual, seasonal pattern, with an increase in incidence during winter and a decrease during summer. Although there is much data on the influenza virus, respiratory syncytial virus, and the SARS outbreak in 2003 following this pattern, it is difficult to predict whether COVID-19 will follow the trend and be eliminated during warmer seasons, since our understanding of the forces driving the seasonality of infectious diseases remains limited. As influenza is a common viral disease, a proportion of the population already possesses some levels of immunity, and when more patients recover, herd immunity constrains the transmission of the virus. The low or absent prevalence of SARS-CoV or the Middle East respiratory syndrome coronavirus (MERS-CoV) in the summer was also observed to have strongly relied on the use of effective therapeutic treatment and strict public health measures [11,12]. However, SARS-CoV-2 is a novel virus among humans, immunity to this ongoing viral pandemic is limited, and an effective pharmaceutical therapy or vaccine is yet to be available.
Seasonality in the outbreak of respiratory infectious diseases may be due to seasonal variations in host physiology (susceptibility, individual immunity, and herd immunity) [13], genetics [14], viral stability [15,16] and infectivity [17-20], presence of latent infectors to spread the virus [21,22], and atmospheric dispersion and transocean intercontinental migration [23-26], which are mainly driven by meteorological factors, including temperature and humidity [17]. Geological features and latitude play a major role in forming a meteorological pattern. Lowen et al [19] assumed the seasonality of influenza and respiratory syncytial virus epidemics in temperate climates were mainly attributable to the low absolute humidity, and specific factors associated with it, namely low temperature, increased population, and low micronutrient levels (such as low vitamin D levels) [27,28]. During the winter in temperate zones, temperature and humidity are low, there is dryness and coldness, and viruses are more easily transmitted via aerosols than direct or indirect contact, where the low temperature renders the virus viable and stable in aerosols and on surfaces. However, in the rainy seasons of tropical regions, where it is hot and wet, aerosol transmission decreases but transmission by direct contact increases [29]. Although high temperatures can decrease the stability of the virus and reduce the level of aerosolization of viral droplets, the amount of virus deposited on surfaces increases as the temperature increases [30].

Because of the relatively stable structure of the coronaviruses, the infectivity of the coronavirus would not be affected by a relative humidity $>95 \%$ and a temperature of $28{ }^{\circ} \mathrm{C}$ to $33{ }^{\circ} \mathrm{C}$ [30]. For example, the transmission of SARS is more efficient in temperatures between $16{ }^{\circ} \mathrm{C}$ and $28^{\circ} \mathrm{C}$, and the wide use of air-conditioning also provides shelter for the breeding and transmission of SARS, where the virus is stable for 3 weeks at room temperature [30]. SARS-CoV-2 has many similarities with SARS-CoV-1, but whether meteorological factors influence viral transmission has not been established. Therefore, in this study, we investigated whether and how meteorological factors affect the spread of COVID-19, with the specific aim of examining the relationship between meteorological factors and the number of COVID-19 daily cases in Asian cities at different latitudes. The objective was to provide scientific evidence concerning the future progression of COVID-19 based on climate factors.

\section{Methods}

\section{Meteorological Data}

We obtained daily meteorological data from the National Meteorological Information Center [31]. The meteorological data of cities in China were collected from the National 
Meteorological Bureau and Data Center of the Ministry of Ecology [32,33] from January 20 to March 18, 2020. The meteorological data in Seoul, Tokyo, Kuala Lumpur, and Singapore were obtained from timeanddate.com [34] from January 20 to March 18, 2020. We retrieved the highest and lowest temperatures and relative humidity for four different quarters of the day and computed the average values of temperature and relative humidity for that day.

\section{COVID-19 Surveillance Data}

The daily number of domestic COVID-19 cases in 5 cities in China (Wuhan, Beijing, Shanghai, Guangzhou, and Hong Kong) and Singapore were obtained from the Ministry of Health in China [35] and Singapore [36], respectively, from the inception of cases to March 18, 2020. Given that the daily number of domestic cases at the city level in Japan, Korea, and Malaysia were not available from their corresponding Ministries of Health, as an alternative, we used the number of domestic cases at the national level in these 3 countries for analysis, which was obtained from the Ministry of Health of Japan, Korea, and Malaysia, respectively. The clinical criterion for the diagnosis of COVID-19 was based on the high-throughput sequencing or reverse transcription polymerase chain reaction assay via nasopharyngeal swab.

\section{Statistical Analysis}

First, the normality of the daily new cases and meteorological data was evaluated by examining their skewness and kurtosis. Subsequently, descriptive analysis was performed to analyze the city-specific characteristics of confirmed COVID-19 cases. Second, to analyze the overall correlation between the two meteorological factors and daily new confirmed cases, Pearson correlation and covariances between the daily COVID-19 new cases and daily meteorological factors were tested, and the linearity between variables was tested using linear regression (with city level and public health measures as controlling factors), as shown in Multimedia Appendix 1. All statistical analyses were performed using STATA 14.0 (Stata Corp).

Subsequently, city-specific generalized additive models (GAMs) with a Poisson family and logarithm link function were used to estimate the associations of daily COVID-19 new cases with average temperature and relative humidity. GAMs are useful for identifying exposure-response relationships from various types of data, particularly in exploring nonparametric relationships [37]. The model was built as follows:

$$
\begin{aligned}
& \text { Daily new cases }{ }_{i} \sim \text { Poisson }\left(\mu_{i}\right) \\
& \log \mu_{i}=\beta_{0}+f_{1}\left(\text { Date }_{i}\right)+f_{2}\left(\text { Temperature }_{i}\right)+ \\
& \left.f_{3} \text { (Relative humidity }_{i}\right)
\end{aligned}
$$

where the terms $f_{1}$ to $f_{2}$ are the smoothing functions, and $\beta_{0}$ is the intercept. The GAM analysis was performed in R software, version 3.6.0 (The R Project for Statistical Computing), using the package "mgcv." We first established a basic temporal model for COVID-19 cases without including meteorological variables. To adjust for long-term trends and seasonality, we included penalized spline functions of time in the model. The degrees of freedom (df) for time was optimized by minimizing the absolute values of the partial autocorrelation function (PACF) of residuals for lags up to 30 days [38-41]. Additionally, the selection of an optimal model was based on the lowest Akaike information criterion (AIC). Next, we built meteorological models based on the temporal models to account for the lagged effect of meteorological variables and the incubation period of COVID-19 $[7,42]$. Specifically, we examined the effect of meteorological variables with different time lags, including 1-day lag (lag 1d), 3-day lag (lag 3d), 5-day lag (lag 5d), single-week lag (lag 7d), and 2-week lag (lag 14d), to capture immediate effects and lagged effects, respectively. Automated penalized splines were used to fit the association between the daily new cases and each of the meteorological variables. The date when the accumulated cases exceeded 30 in each city or country was selected as the inception of the date incorporated in the model to equalize the starting speed of outbreak and thus avoid misinterpretation and overfitting.

To control for the autocorrelation, the model's residuals were examined for serial correlation using PACF. Default plots showing the smooth components of a fitted GAM were produced. The percentage of deviance explained by each variable was calculated, which represents the scale of a linear predictor that contributes to the component smooth functions. At last, the graph of smooth components was grouped based on similar latitudes to mitigate the influence by latitude.

\section{Sensitivity Analysis}

To verify model results, a sensitivity analysis was performed. Owing to the different public health measures put forward in different cities or countries, the city scale was taken into consideration in the model. We postulated that the during the following 15 days after the accumulated cases exceeded 40, public health measures and precautions were not readily available; thus, the transmission of the disease resembles natural transmission. The model was built as follows:

$$
\begin{aligned}
& \text { Daily new } \text { cases }_{i} \sim \text { Poisson }\left(\mu_{i}\right) \\
& \log \mu_{i}=\beta_{0}+f_{1}\left(\text { Date }_{i}\right)+f_{2}\left(\text { Temperature }_{i}\right)+ \\
& f_{3}\left(\text { Relative humidity }_{i}\right)+f_{4}\left({\text { City } \left.\text { level }_{i}\right)}\right.
\end{aligned}
$$

where the terms $f_{1}$ is the smoothing functions, $f_{2-4}$ are the linear functions, and $\beta_{0}$ is the intercept. GAM with linear components facilitate the analysis of the effects of explanatory variables in a way that closely resembles the analysis of covariates in a standard linear model, but with less confining assumptions. This is achieved by specifying a link function, which links the systematic component of the linear model with a wider class of outcome variables and residual forms.

\section{Results}

\section{Descriptive Statistical Results}

The daily new cases of COVID-19 and meteorological data from January 20 to March 18, 2020 (61 days), in 9 different cities are shown in Tables 1 and 2. During the study period, the temperature in the 5 cities in China ranged from $-9^{\circ} \mathrm{C}$ to 26.25 ${ }^{\circ} \mathrm{C}$ (Beijing: $-9{ }^{\circ} \mathrm{C}$ to $26{ }^{\circ} \mathrm{C}$; Shanghai: $0{ }^{\circ} \mathrm{C}$ to $22{ }^{\circ} \mathrm{C}$; Guangzhou $8.75{ }^{\circ} \mathrm{C}$ to $26.25{ }^{\circ} \mathrm{C}$; Wuhan: $1{ }^{\circ} \mathrm{C}$ to $21.75{ }^{\circ} \mathrm{C}$; Hong Kong: $11.25{ }^{\circ} \mathrm{C}$ to $26.25{ }^{\circ} \mathrm{C}$ ). The temperature in Singapore ranged from $25.5^{\circ} \mathrm{C}$ to $32.75^{\circ} \mathrm{C}$; in Seoul, from -9.5 
${ }^{\circ} \mathrm{C}$ to $12.25^{\circ} \mathrm{C}$; in Tokyo, from $0.75^{\circ} \mathrm{C}$ to $18.5^{\circ} \mathrm{C}$; and in Kuala associated with average temperature and average relative Lumpur, from $24.5^{\circ} \mathrm{C}$ to $33.5^{\circ} \mathrm{C}$. Multimedia Appendices 2 humidity over time, respectively. and 3 show the distribution of daily COVID-19 new cases

Table 1. Descriptive statistics for different Asian cities.

\begin{tabular}{|c|c|c|c|c|c|c|}
\hline Variables (latitude) & Mean (SD) & Minimum & Q1 & Median & Q3 & Maximum \\
\hline \multicolumn{7}{|l|}{ Beijing, China $\left(39^{\circ} 56^{\prime} \mathrm{N}\right)$} \\
\hline Domestic case (persons) & $8.00(9.60)$ & 0.00 & 1.00 & 5.00 & 12.00 & 39.00 \\
\hline Highest temperature $\left({ }^{\circ} \mathrm{C}\right)$ & $8.29(5.34)$ & -4.00 & 5.00 & 8.00 & 11.00 & 26.00 \\
\hline Lowest temperature $\left({ }^{\circ} \mathrm{C}\right)$ & $-3.10(3.44)$ & -9.00 & -6.00 & -3.00 & -1.00 & 4.00 \\
\hline Relative humidity (\%) & $52.49(19.48)$ & 23.50 & 36.25 & 54.75 & 67.00 & 92.75 \\
\hline \multicolumn{7}{|l|}{ Shanghai, China $\left(31^{\circ} 14^{\prime} \mathbf{N}\right)$} \\
\hline Domestic case (persons) & $7.00(8.20)$ & 0.00 & 0.00 & 3.00 & 13.00 & 27.00 \\
\hline Highest temperature $\left({ }^{\circ} \mathrm{C}\right)$ & $11.34(3.61)$ & 4.00 & 8.75 & 10.75 & 13.50 & 21.50 \\
\hline Lowest temperature $\left({ }^{\circ} \mathrm{C}\right)$ & $8.28(3.18)$ & 1.50 & 6.25 & 8.25 & 10.25 & 15.00 \\
\hline Relative humidity (\%) & $71.11(14.70)$ & 42.00 & 60.00 & 71.75 & 82.50 & 94.75 \\
\hline \multicolumn{7}{|l|}{ Wuhan, China $\left(30^{\circ} 37^{\prime} \mathbf{N}\right)$} \\
\hline Domestic case (persons) & $1035.00(1968.80)$ & 0.00 & 120.00 & 502.50 & 1524.50 & $13,436.00$ \\
\hline Highest temperature $\left({ }^{\circ} \mathrm{C}\right)$ & $11.45(4.40)$ & 3.50 & 8.00 & 11.00 & 14.00 & 20.75 \\
\hline Lowest temperature $\left({ }^{\circ} \mathrm{C}\right)$ & $8.22(3.76)$ & 1.50 & 5.25 & 8.25 & 11.00 & 17.50 \\
\hline Relative humidity (\%) & $74.03(11.70)$ & 51.75 & 66.25 & 74.75 & 84.75 & 93.25 \\
\hline \multicolumn{7}{|l|}{ Guangzhou, China $\left(2^{\circ} 1^{\prime} \mathrm{N}\right)$} \\
\hline Domestic case (persons) & $7.00(9.80)$ & 0.00 & 0.00 & 3.00 & 12.00 & 38.00 \\
\hline Highest temperature $\left({ }^{\circ} \mathrm{C}\right)$ & $19.32(3.95)$ & 11.25 & 16.25 & 20.00 & 22.00 & 26.25 \\
\hline Lowest temperature $\left({ }^{\circ} \mathrm{C}\right)$ & $16.55(3.82)$ & 8.75 & 13.75 & 17.00 & 19.75 & 22.50 \\
\hline Relative humidity (\%) & $67.95(13.19)$ & 34.75 & 60.00 & 68.75 & 78.50 & 87.50 \\
\hline \multicolumn{7}{|l|}{ Hong Kong, China $\left(22^{\circ} 15^{\prime} \mathrm{N}\right)$} \\
\hline Domestic case (persons) & $2.00(2.50)$ & 0.00 & 0.00 & 1.50 & 3.00 & 13.00 \\
\hline Highest temperature $\left({ }^{\circ} \mathrm{C}\right)$ & $20.66(3.11)$ & 13.50 & 18.50 & 21.00 & 23.25 & 26.25 \\
\hline Lowest temperature $\left({ }^{\circ} \mathrm{C}\right)$ & $18.39(3.12)$ & 11.25 & 16.50 & 19.25 & 20.50 & 24.25 \\
\hline Relative humidity (\%) & $70.31(12.67)$ & 31.00 & 65.00 & 74.00 & 79.00 & 88.50 \\
\hline
\end{tabular}


Table 2. Descriptive statistics for different Asian cities, continued.

\begin{tabular}{|c|c|c|c|c|c|c|}
\hline Variables (latitude) & Mean (SD) & Minimum & Q1 & Median & Q3 & Maximum \\
\hline \multicolumn{7}{|l|}{ Singapore $\left(1^{\circ} 18^{\prime} \mathbf{N}\right)$} \\
\hline Domestic case (persons) & $3.00(3.10)$ & 0.00 & 1.00 & 3.00 & 4.00 & 14.00 \\
\hline Highest temperature $\left({ }^{\circ} \mathrm{C}\right)$ & $30.46(0.97)$ & 27.75 & 29.75 & 30.50 & 31.25 & 32.75 \\
\hline Lowest temperature $\left({ }^{\circ} \mathrm{C}\right)$ & $27.64(0.77)$ & 26.00 & 27.25 & 27.75 & 28.25 & 29.00 \\
\hline Relative humidity (\%) & $76.09(4.95)$ & 63.75 & 73.25 & 75.50 & 79.25 & 89.50 \\
\hline \multicolumn{7}{|l|}{ Seoul, Korea $\left(37^{\circ} 33^{\prime} \mathbf{N}\right)$} \\
\hline Domestic case (persons) & $142.00(216.00)$ & 0.00 & 0.00 & 3.00 & 210.00 & 909.00 \\
\hline Highest temperature $\left({ }^{\circ} \mathrm{C}\right)$ & $5.45(3.93)$ & -6.00 & 3.25 & 6.25 & 8.00 & 12.25 \\
\hline Lowest temperature $\left({ }^{\circ} \mathrm{C}\right)$ & $0.95(3.56)$ & -9.50 & -1.25 & 1.50 & 3.75 & 6.25 \\
\hline Relative humidity (\%) & $68.50(10.78)$ & 48.25 & 59.50 & 66.75 & 76.75 & 91.50 \\
\hline \multicolumn{7}{|l|}{ Tokyo, Japan $\left(35^{\circ} 69^{\prime} \mathrm{N}\right)$} \\
\hline Domestic case (persons) & $15.00(17.90)$ & 0.00 & 0.00 & 8.00 & 25.00 & 60.00 \\
\hline Highest temperature $\left({ }^{\circ} \mathrm{C}\right)$ & $10.30(3.11)$ & 3.50 & 8.75 & 10.25 & 12.50 & 18.50 \\
\hline Lowest temperature $\left({ }^{\circ} \mathrm{C}\right)$ & $6.92(2.65)$ & 0.75 & 5.25 & 6.75 & 8.75 & 14.00 \\
\hline Relative humidity (\%) & $61.41(17.52)$ & 32.75 & 47.25 & 59.50 & 76.25 & 97.75 \\
\hline \multicolumn{7}{|c|}{ Kuala Lumpur, Malaysia $\left(3^{\circ} 8^{\prime} \mathbf{N}\right)$} \\
\hline Domestic case (persons) & $14.00(37.20)$ & 0.00 & 0.00 & 0.00 & 7.00 & 190.00 \\
\hline Highest temperature $\left({ }^{\circ} \mathrm{C}\right)$ & $30.98(1.26)$ & 26.50 & 30.25 & 31.00 & 31.75 & 33.50 \\
\hline Lowest temperature $\left({ }^{\circ} \mathrm{C}\right)$ & $27.19(1.03)$ & 24.50 & 26.50 & 27.25 & 28.00 & 29.00 \\
\hline Relative humidity (\%) & $77.19(6.74)$ & 62.50 & 74.00 & 77.50 & 82.25 & 92.50 \\
\hline
\end{tabular}

To test the potential collinearity between the meteorological parameters, a series of Pearson correlations and covariances, as well as linear regressions were conducted (Table 3 and Multimedia Appendix 1). Daily confirmed new cases were negatively correlated with average temperature in Beijing $(r=-0.565, \quad P<.001)$, Shanghai $(r=-0.471, \quad P<.001)$, and
Guangzhou $(r=-0.530, P<.001)$. In contrast, Japan exhibited a positive correlation $(r=0.416, P<.001)$. The correlation between average temperature and relative humidity was found to be positive in Shanghai, Guangzhou, Hong Kong, Korea, and Japan, and negative in Beijing, Wuhan, Singapore, and Malaysia, according to the pairwise Pearson correlation test (Table 3). 
Table 3. Pearson correlation coefficient $(r)$ between daily new COVID-19 cases and meteorological factors.

\begin{tabular}{|c|c|c|c|c|}
\hline \multirow[t]{2}{*}{ Variables } & \multicolumn{2}{|c|}{ Daily new cases } & \multicolumn{2}{|c|}{ Average temperature } \\
\hline & $r$ & $P$ value & $r$ & $P$ value \\
\hline \multicolumn{5}{|l|}{ Beijing, China } \\
\hline Daily new cases & 1.00 & $\underline{\mathrm{a}}^{\mathrm{a}}$ & - & - \\
\hline Average temperature & -0.57 & $<.001$ & 1.00 & - \\
\hline Humidity & 0.15 & .30 & -0.26 & .05 \\
\hline \multicolumn{5}{|l|}{ Shanghai, China } \\
\hline Daily new cases & 1.00 & - & - & - \\
\hline Average temperature & -0.47 & $<.001$ & 1.00 & - \\
\hline Humidity & -0.11 & .45 & 0.09 & .50 \\
\hline \multicolumn{5}{|l|}{ Wuhan, China } \\
\hline Daily new cases & 1.00 & - & - & - \\
\hline Average temperature & 0.04 & .81 & 1.00 & - \\
\hline Humidity & 0.10 & .48 & -0.42 & $<.001$ \\
\hline \multicolumn{5}{|l|}{ Guangzhou, China } \\
\hline Daily new cases & 1.00 & - & - & - \\
\hline Average temperature & -0.53 & $<.001$ & 1.00 & - \\
\hline Humidity & -0.29 & .05 & 0.34 & .01 \\
\hline \multicolumn{5}{|l|}{ Hong Kong, China } \\
\hline Daily new cases & 1.00 & - & - & - \\
\hline Average temperature & 0.08 & .56 & 1.00 & - \\
\hline Humidity & 0.07 & .60 & 0.58 & $<.001$ \\
\hline \multicolumn{5}{|l|}{ Singapore } \\
\hline Daily new cases & 1.00 & - & - & - \\
\hline Average temperature & 0.27 & .04 & 1.00 & - \\
\hline Humidity & 0.04 & .74 & -0.58 & $<.001$ \\
\hline \multicolumn{5}{|l|}{ Seoul, Korea } \\
\hline Daily new cases & 1.00 & - & - & - \\
\hline Average temperature & 0.29 & .02 & 1.00 & - \\
\hline Humidity & 0.14 & .30 & 0.32 & .01 \\
\hline \multicolumn{5}{|l|}{ Tokyo, Japan } \\
\hline Daily new cases & 1.00 & - & - & - \\
\hline Average temperature & 0.42 & $<.001$ & 1.00 & - \\
\hline Humidity & 0.20 & .14 & 0.21 & .11 \\
\hline \multicolumn{5}{|l|}{ Kuala Lumpur, Malaysia } \\
\hline Daily new cases & 1.00 & - & - & - \\
\hline Average temperature & 0.21 & .11 & 1.00 & - \\
\hline Humidity & -0.17 & .20 & -0.74 & $<.001$ \\
\hline
\end{tabular}

${ }^{\mathrm{a}}$ Not applicable. 
City-Specific GAM Analysis of Daily New COVID-19 Cases With Meteorological Factors

The final GAM model of daily new COVID-19 cases incorporated date (time-series), average temperature, and mean relative humidity. All estimates and significance levels were listed in Multimedia Appendix 1. The models with the best performance (lowest AIC) for each city were as follows: no-lag model for Shanghai and Singapore; lag 1d model for Beijing and Wuhan; lag 5d model for Guangzhou, Korea, and Kuala Lumpur; and lag 14d model for Hong Kong and Japan (Table 4).

GAM results were reported using the smoothing components plot for temperature and relative humidity in Multimedia Appendices 4 and 5, respectively. The smoothing components plots demonstrated the estimated smoothing spline functions with the linear effect subtracted out, and each panel represented the weighted sum of basis functions for each time-varying covariate and corresponds to the hypothesized model.
The significant smoothers indicated that the correlations between new cases of COVID-19 and explanatory variables were nonlinear. As shown in Multimedia Appendix 4, the no-lag model suggested that holding all linear and the other nonlinear terms fixed, daily new cases of COVID-19 were not influenced by the temperature, but the case number decreased when the temperature reached $5{ }^{\circ} \mathrm{C}, 18{ }^{\circ} \mathrm{C}$, and $29^{\circ} \mathrm{C}$ in Beijing, Hong Kong, and Singapore, respectively $(P<.01$ for all; Multimedia Appendix 4). While the magnitude of the results may look small relative to the base rate of case accrual, these plots were on the log-case scale, so the effect on the case number is multiplicative. The distributions of COVID-19 cases displayed greater uncertainty at a lower temperature in Beijing and Wuhan. Beijing and Wuhan have fluctuating patterns throughout the 6 models both regarding temperature and relative humidity except in the lag $5 \mathrm{~d}$ and lag $4 \mathrm{~d}$ models for Wuhan, which may be due to the change in diagnostic method on February 12, when a total of 13,436 cases were added. Nevertheless, the relationship between relative humidity and new cases were less evident in the no-lag model, and the distributions of COVID-19 cases displayed greater uncertainty in Wuhan. 
Table 4. The selection of generalized additive modeling by Akaike information criterion (AIC).

\begin{tabular}{|c|c|c|}
\hline City and model & $d f$ & AIC \\
\hline \multicolumn{3}{|l|}{ Beijing, China } \\
\hline No lag & 24.01 & 265.47 \\
\hline $\operatorname{Lag} 1 \mathrm{~d}^{\mathrm{a}}$ & 21.71 & 226.47 \\
\hline Lag 3d & 17.72 & 273.59 \\
\hline Lag $5 d$ & 21.46 & 263.25 \\
\hline Lag $7 d$ & 23.38 & 243.26 \\
\hline Lag 14 & 19.79 & 230.50 \\
\hline \multicolumn{3}{|c|}{ Shanghai, China } \\
\hline No lag ${ }^{\mathrm{a}}$ & 7.91 & 178.01 \\
\hline Lag $1 \mathrm{~d}$ & 7.50 & 181.60 \\
\hline Lag $3 d$ & 7.04 & 180.93 \\
\hline Lag $5 d$ & 7.08 & 180.60 \\
\hline Lag $7 d$ & 6.83 & 182.73 \\
\hline Lag 14 & 10.51 & 178.06 \\
\hline \multicolumn{3}{|c|}{ Guangzhou, China } \\
\hline No lag & 14.17 & 199.85 \\
\hline Lag 1d & 14.40 & 192.44 \\
\hline Lag 3d & 18.32 & 194.49 \\
\hline Lag $5 d^{\mathrm{a}}$ & 20.97 & 192.35 \\
\hline Lag $7 d$ & 10.63 & 200.94 \\
\hline Lag 14 & 12.89 & 195.34 \\
\hline \multicolumn{3}{|l|}{ Wuhan, China } \\
\hline No lag & 27.95 & 4812.57 \\
\hline $\operatorname{Lag} 1 \mathrm{~d}^{\mathrm{a}}$ & 27.87 & 3637.25 \\
\hline Lag $3 d$ & 27.89 & 6778.17 \\
\hline Lag $5 d$ & 27.98 & 5344.86 \\
\hline $\operatorname{Lag} 7 d$ & 27.86 & $10,351.23$ \\
\hline Lag 14 & 26.45 & 6735.71 \\
\hline \multicolumn{3}{|c|}{ Hong Kong, China } \\
\hline No lag & 12.46 & 193.98 \\
\hline Lag 1d & 16.49 & 192.14 \\
\hline Lag $3 d$ & 11.92 & 195.65 \\
\hline Lag $5 d$ & 14.12 & 193.45 \\
\hline Lag $7 d$ & 13.17 & 199.01 \\
\hline $\operatorname{Lag} 14^{\mathrm{a}}$ & 6.53 & 189.09 \\
\hline \multicolumn{3}{|l|}{ Singapore } \\
\hline No lag ${ }^{\mathrm{a}}$ & 10.94 & 183.22 \\
\hline Lag 1d & 10.88 & 185.19 \\
\hline Lag $3 d$ & 9.57 & 202.13 \\
\hline Lag $5 d$ & 10.83 & 207.79 \\
\hline Lag 7d & 16.18 & 230.09 \\
\hline
\end{tabular}




\begin{tabular}{|c|c|c|}
\hline City and model & $d f$ & AIC \\
\hline Lag 14 & 14.83 & 277.87 \\
\hline \multicolumn{3}{|l|}{ Seoul, Korea } \\
\hline No lag & 27.54 & 461.16 \\
\hline Lag 1d & 25.86 & 381.98 \\
\hline Lag $3 d$ & 27.19 & 439.14 \\
\hline Lag $5 d^{\mathrm{a}}$ & 26.67 & 363.42 \\
\hline Lag 7d & 26.24 & 420.27 \\
\hline Lag 14 & 27.29 & 452.58 \\
\hline \multicolumn{3}{|l|}{ Tokyo, Japan } \\
\hline No lag & 24.58 & 264.80 \\
\hline Lag 1d & 19.77 & 266.44 \\
\hline Lag $3 d$ & 24.37 & 276.50 \\
\hline Lag $5 d$ & 18.28 & 272.25 \\
\hline Lag $7 d$ & 17.61 & 288.62 \\
\hline $\operatorname{Lag} 14^{\mathrm{a}}$ & 18.33 & 264.45 \\
\hline \multicolumn{3}{|c|}{ Kuala Lumpur, Malaysia } \\
\hline No lag & 16.37 & 142.50 \\
\hline Lag 1d & 16.74 & 138.72 \\
\hline Lag 3d & 21.70 & 132.95 \\
\hline $\operatorname{Lag} 5 \mathrm{~d}^{\mathrm{a}}$ & 17.93 & 125.05 \\
\hline $\operatorname{Lag} 7 d$ & 19.80 & 132.67 \\
\hline Lag 14 & 21.58 & 133.89 \\
\hline
\end{tabular}

${ }^{\mathrm{a}}$ Denotes the model with the lowest AIC value.

\section{Sensitivity Analysis of Daily New COVID-19 Cases With Meteorological Factors}

After taking the city level into consideration in the model, a GAM model of daily new COVID-19 cases was built, incorporating date (time-series), city level, average temperature, and mean relative humidity, where the date was analyzed as spline functions.

Overall, we found a significant association between meteorological factors and daily new cases of COVID-19 in 9

Asian cities. Under GAM, high temperature tended to increase the number of daily new cases of COVID-19 whereas high relative humidity decreased the count (Table 5). Relative humidity does not influence the daily new cases significantly, but higher temperatures can exert an increase as high as $7 \%$ on daily new cases in lag $3 \mathrm{~d}$ (beta $=0.073$, SE $0.006, P<.001$; Table 4). The time-series analysis revealed that notwithstanding the lagged time effects, the overall influence of temperature was steadily positive. Nevertheless, the relative humidity exerted a negative influence on the transmission of daily new cases of COVID-19 (Table 5). 
Table 5. Generalized linear modeling of the effects of temperature and relative humidity on daily new cases of COVID-19.

\begin{tabular}{|c|c|c|c|c|}
\hline Model & Estimate & Standard error & $Z$ value & $P$ value \\
\hline \multicolumn{5}{|l|}{ No-lag model } \\
\hline Temperature & 0.062 & 0.006 & 10.861 & $<.001$ \\
\hline Relative humidity & -0.018 & 0.001 & -15.105 & $<.001$ \\
\hline \multicolumn{5}{|l|}{ Lag 1d model } \\
\hline Temperature & 0.015 & 0.007 & 2.284 & .02 \\
\hline Relative humidity & -0.007 & 0.001 & -6.513 & $<.001$ \\
\hline \multicolumn{5}{|l|}{ Lag 3d model } \\
\hline Temperature & 0.073 & 0.006 & 11.594 & $<.001$ \\
\hline Relative humidity & -0.006 & 0.001 & -4.501 & $<.001$ \\
\hline \multicolumn{5}{|l|}{ Lag 5d model } \\
\hline Temperature & -0.026 & 0.006 & -4.152 & $<.001$ \\
\hline Relative humidity & 0.003 & 0.001 & 2.471 & .01 \\
\hline \multicolumn{5}{|l|}{ Lag 7d model } \\
\hline Temperature & 0.063 & 0.005 & 13.887 & $<.001$ \\
\hline Relative humidity & -0.008 & 0.001 & -6.620 & $<.001$ \\
\hline
\end{tabular}

\section{Discussion}

\section{Principal Findings}

In this study, we investigated the associations between meteorological factors and patterns of daily new cases of COVID-19 across 9 Asian cities. The city-specific GAM analysis revealed a positive relationship between temperature and daily new cases of COVID-19 in Guangzhou, Singapore (except in the lagged 14-day model), Hong Kong (except in the lagged 7-day and 14-day model), and Beijing (high curvilinearity). Relative humidity positively associated with the number of daily new cases in Singapore (except in the lagged 14-day model), Hong Kong (except in the lagged 3-day model). Moreover, the sensitivity test using GAM with linear components revealed that high temperature significantly increases the daily new cases of COVID-19, while high relative humidity significantly reduced, to a lower extent, the daily new cases of COVID-19. Therefore, our analysis suggests, unlike influenza, seasonality of COVID-19 may not be expected, and the pandemic is unlikely to diminish during warmer seasons (ie, summer).

Researchers have long been investigating how meteorological factors affect the viral infectivity, where GAM has been frequently used, as it allows smooth components to be estimated for time, meteorological factors, and other covariates, together with a nonsmoothed period effect. Experiments from the mid-20th century reported that the influenza virus is more stable in cool and dry air $[15,16]$. With increasing temperature, the viability of the influenza virus in aerosol or droplets [43] and the aerosol transmission diminishes [17]. Lowen et al [19] reported that aerosol transmission of influenza between guinea pigs was completely blocked at temperature higher than $30{ }^{\circ} \mathrm{C}$ despite evidence of continuous viral shedding from infectious individuals; nevertheless, direct contact transmission was not affected, which was equally efficient at $30^{\circ} \mathrm{C}$ and $20^{\circ} \mathrm{C}$. Chan

et al [30] reported that the viability of the SARS virus was rapidly lost $(>3 \log 10)$ at high temperatures $\left(38^{\circ} \mathrm{C}\right)$ and high relative humidity $(>95 \%)$. The better stability of the SARS coronavirus at low temperatures and low humidity environment might facilitate its transmission in the community in subtropical areas (such as Hong Kong) during the spring and in air-conditioned environments. This might also explain why some Asian countries in tropical areas (such as Malaysia, Indonesia, or Thailand) with high temperatures and high relative humidity environment did not have major community outbreaks of SARS. However, such an explanation is not currently convincing in light of the results of the present study, where higher temperatures were associated with increases in the daily new cases of COVID-19 in some of the investigated regions. The high temperature and high relative humidity in tropical Asian countries like Singapore and Malaysia also seem to have little influence on the growing number of daily new cases (Multimedia Appendix 4). However, this could have been confounded by multiple factors.

There are several reasons underlying the continuous growth in COVID-19 cases in Singapore and Malaysia, such as the high population density, mass gatherings, use of air-conditioning, and shortage of medical resources [30]. SARS-CoV-2 can persist at room temperature for up to 9 days, and its heat sensitivity renders it susceptible to increased temperature, affecting its persistence in the outdoor environment. However, this coronavirus was still found to be infective up to 2 weeks in an air-conditioned environment [30]. As air-conditioners may increase the probability of viral spread, it may be advisable to reduce the use of air-conditioners and keep areas well ventilated [44]. Moreover, during low temperature and high humidity, it is advisable to avoid mass gatherings, since there is evidence supporting transmission by direct contact or close contact in tropical areas. 
Humidity can influence aerosol transmission by altering the proportion of respiratory droplets undergoing aerosolization and influencing the stability and viability of the virus within these aerosols. Respiratory droplets are generated in the high humidity setting of the respiratory tract. Upon entering an environment with low humidity, respiratory droplets reduce in size within seconds due to evaporation. At higher environmental humidity, respiratory droplets evaporate more slowly, and hence are larger and settle faster, and less aerosol nuclei are produced $[45,46]$. Previous studies have shown that influenza transmission in mice decreased as relative humidity increased from $47 \%$ to $70 \%[13,47]$. Moreover, humidity can also influence indirect transmission by changing the mass of respiratory droplets accumulating on surfaces and affecting the survival of the virus on surfaces. While increased humidity reduces the number of droplet nuclei formed, the same mechanisms (reduced droplet evaporation and faster droplet settling) result in a greater mass of respiratory droplets on surfaces [45,46]. Areas with relatively low temperature and humidity have a higher infection rate compared to tropical areas since cold and dry weather is suitable for viral survival and transmission [48]. The viability of the influenza virus appears greater at lower humidity, and exhibits progressively reduced survival with increasing relative humidity over the $27 \%-84 \%$ range, with an increase in survival at $99 \%$ relative humidity. The mechanisms underlying this may be that the reduced evaporation of droplets at high relative humidity maintain the solute concentration, thus protecting the virus $[17,49]$. In addition, the $30^{\circ} \mathrm{N}$ to $50^{\circ} \mathrm{N}$ latitudes have become a zone for COVID-19 transmission with a similar average temperature between $5{ }^{\circ} \mathrm{C}$ and $11{ }^{\circ} \mathrm{C}$ and $47 \%-79 \%$ humidity, which may be influenced by the transoceanic migration of the virus, but the underlying mechanism is still not understood [50].

Moreover, under laboratory conditions with constant humidity and temperature, circadian and circannual rhythms in variation of susceptibility of hosts (mice) have been observed [13,51]. Mice were substantially more susceptible to invasive pneumococcal disease in early morning hours than any other time of day [51], and more susceptible to influenza in winter than in summer [13], which was thought to be attributable to the daily and seasonal variation of melatonin [52]. In addition, even in areas where many spend summers in air-conditioned spaces, marked annual variations in incidence constantly exist, and similar strains of the virus appear almost simultaneously across vast stretches of ocean in areas of similar latitude around the globe [23,24].

Therefore, although a higher temperature is associated with lower effectiveness of virus transmission, yet it does not necessarily suggest a reduced chance for virus survival. The natural fading out of the virus in the summer is unlikely given the widespread use of air-conditioners in developed areas and dense populations in cities. Until an effective vaccine becomes widely available for the establishment of herd immunity, alongside efficient pharmaceutical therapies, strict public health measures should be implemented, including social distancing, quarantine, contact tracing, face mask wearing, and hand washing.

\section{Strengths and Limitations}

This is the first study to statistically analyze the relationship between meteorological factors and the daily new cases of COVID-19. Because of the nonlinear nature of the data, we also performed GAMs to quantitate and visualize the relationship using spline functions. However, there are several limitations. First, the number of cases in Malaysia, Korea, and Japan were obtained from the epidemiologic reports released by the Department of Health in the corresponding countries, instead of a daily update of case numbers, which was not available for these countries. Hence, some cases may be missing. Second, the duration of the study period was short and the number of cases in Malaysia, Singapore, and Japan were small. Third, we only considered two meteorological factors (temperature and humidity) in this study. Other covariates such as wind speed, pollutant concentration, population density, air-conditioning use, and rainfall, which could also influence the spread of COVID-19, were not included. Moreover, while we collected the meteorological data from the capital cities of Malaysia, Japan, and Korea, the number of domestic cases at the national level in these three countries was used for analysis due to lack of available data at their city level. Most importantly, we did not incorporate public health measures into the modeling, which may greatly confound the results, but we chose the date when accumulated confirmed cases exceeded 30, based on the postulation that a certain level of public health measures had been carried out at that time; thus, the confounding effects can be mitigated at some point.

\section{Conclusions}

In this study, we found high temperature to be associated with daily new cases of COVID-19. Therefore, unlike influenza, seasonality in COVID-19 prevalence may not be expected, and the pandemic is unlikely to decrease in numbers during the warmer seasons. Strict public health measures such as social distancing, quarantine, contact tracing, face mask wearing, and hand washing are needed until a vaccine becomes widely available to induce herd immunity.

\section{Conflicts of Interest}

None declared.

\section{Multimedia Appendix 1}

The effects of temperature and relative humidity on daily new cases of COVID-19.

[DOCX File, 29 KB-Multimedia Appendix 1] 


\section{Multimedia Appendix 2}

Daily temperature and distribution of daily new cases of COVID-19 over time.

[PNG File, 919 KB-Multimedia Appendix 2]

\section{Multimedia Appendix 3}

Daily relative humidity and distribution of daily new COVID-19 cases over time.

[PNG File, 861 KB-Multimedia Appendix 3]

\section{Multimedia Appendix 4}

Smoothing components plots for daily new COVID-19 cases associated with average temperature.

[PNG File, 1329 KB-Multimedia Appendix 4]

\section{Multimedia Appendix 5}

Smoothing components plots for daily new COVID-19 cases associated with average relative humidity. [PNG File, 1278 KB-Multimedia Appendix 5]

\section{References}

1. Chen N, Zhou M, Dong X, Qu J, Gong F, Han Y, et al. Epidemiological and clinical characteristics of 99 cases of 2019 novel coronavirus pneumonia in Wuhan, China: a descriptive study. The Lancet 2020 Feb;395(10223):507-513. [doi: 10.1016/S0140-6736(20)30211-7]

2. Statement on the second meeting of the International Health Regulations (2005) Emergency Committee regarding the outbreak of novel coronavirus (2019-nCoV). World Health Organization. 2020 Jan 30. URL: https://tinyurl.com/rjdtx2k [accessed 2020-02-24]

3. Xu X, Chen P, Wang J, Feng J, Zhou H, Li X, et al. Evolution of the novel coronavirus from the ongoing Wuhan outbreak and modeling of its spike protein for risk of human transmission. Sci China Life Sci 2020 Mar;63(3):457-460 [FREE Full text] [doi: 10.1007/s11427-020-1637-5] [Medline: 32009228]

4. Gralinski LE, Menachery VD. Return of the Coronavirus: 2019-nCoV. Viruses 2020 Jan 24;12(2):135 [FREE Full text] [doi: 10.3390/v12020135] [Medline: 31991541]

5. Cowling B, Leung G. Epidemiological research priorities for public health control of the ongoing global novel coronavirus (2019-nCoV) outbreak. Euro Surveill 2020 Feb;25(6):2020 [ㅍREE Full text] [doi: 10.2807/1560-7917.ES.2020.25.6.2000110] [Medline: 32046814]

6. Tang J. The emergence and spread of the 2019 novel coronavirus (2019-nCoV). Infectious Diseases Hub. 2020. URL: https://www.id-hub.com/2020/02/10/the-emergence-and-spread-of-the-2019-novel-coronavirus-2019-ncov/ [accessed 2020-02-24]

7. Riou J, Althaus CL. Pattern of early human-to-human transmission of Wuhan 2019 novel coronavirus (2019-nCoV), December 2019 to January 2020. Euro Surveill 2020 Jan;25(4) [FREE Full text] [doi: 10.2807/1560-7917.ES.2020.25.4.2000058] [Medline: 32019669]

8. Lauer SA, Grantz KH, Bi Q, Jones FK, Zheng Q, Meredith HR, et al. The Incubation Period of Coronavirus Disease 2019 (COVID-19) From Publicly Reported Confirmed Cases: Estimation and Application. Annals of Internal Medicine 2020 May 05;172(9):577-582. [doi: 10.7326/m20-0504]

9. Lai C, Shih T, Ko W, Tang H, Hsueh P. Severe acute respiratory syndrome coronavirus 2 (SARS-CoV-2) and coronavirus disease-2019 (COVID-19): The epidemic and the challenges. Int J Antimicrob Agents 2020 Mar;55(3):105924 [FREE Full text] [doi: 10.1016/j.ijantimicag.2020.105924] [Medline: $\underline{\text { 32081636] }}$

10. WHO Director-General's opening remarks at the Mission briefing on COVID-19 - 12 March 2020. World Health Organization. 2020. URL: https://www.who.int/director-general/speeches/detail/ who-director-general-s-opening-remarks-at-the-mission-briefing-on-covid-19---12-march-2020 [accessed 2020-03-15]

11. de Wit E, van Doremalen N, Falzarano D, Munster VJ. SARS and MERS: recent insights into emerging coronaviruses. Nat Rev Microbiol 2016 Aug 27;14(8):523-534 [FREE Full text] [doi: 10.1038/nrmicro.2016.81] [Medline: 27344959]

12. Cai Q, Lu J, Xu Q, Guo Q, Xu D, Sun Q, et al. Influence of meteorological factors and air pollution on the outbreak of severe acute respiratory syndrome. Public Health 2007 Apr;121(4):258-265 [FREE Full text] [doi: 10.1016/j.puhe.2006.09.023] [Medline: 17307207]

13. Schulman J, Kilbourne E. Experimental Transmission of Influenza Virus Infection in Mice. II. Some Factors Affecting the Incidence of Transmitted Infection. J Exp Med 1963;118(2):267-275. [doi: 10.1084/jem.118.2.267]

14. Horby P, Nguyen N, Dunstan S, Baillie JK. The role of host genetics in susceptibility to influenza: a systematic review. PLoS One 2012;7(3):e33180 [FREE Full text] [doi: 10.1371/journal.pone.0033180] [Medline: 22438897] 
15. Hemmes JH, Winkler KC, Kool SM. Virus Survival as a Seasonal Factor in Influenza and Poliomyelitis. Nature 1960 Oct;188(4748):430-431. [doi: 10.1038/188430a0]

16. Loosli CG, Lemon HM, Robertson OH, Appel E. Experimental Air-Borne Influenza Infection. I. Influence of Humidity on Survival of Virus in Air. Experimental Biology and Medicine 1943 Jun 01;53(2):205-206. [doi:

10.3181/00379727-53-14251p]

17. Paynter S. Humidity and respiratory virus transmission in tropical and temperate settings. Epidemiol Infect 2015 Apr;143(6):1110-1118. [doi: 10.1017/S0950268814002702] [Medline: 25307020]

18. Finkelman BS, Viboud C, Koelle K, Ferrari MJ, Bharti N, Grenfell BT. Global patterns in seasonal activity of influenza A/H3N2, A/H1N1, and B from 1997 to 2005: viral coexistence and latitudinal gradients. PLoS One 2007 Dec 12;2(12):e1296 [FREE Full text] [doi: 10.1371/journal.pone.0001296] [Medline: 18074020]

19. Lowen AC, Steel J, Mubareka S, Palese P. High Temperature $\left(30^{\circ} \mathrm{C}\right)$ Blocks Aerosol but Not Contact Transmission of Influenza Virus. JVI 2008 Jun 01;82(11):5650-5652. [doi: 10.1128/jvi.00325-08]

20. Coronavirus disease 2019 (COVID-19) Situation Report - 28. World Health Organization. 2020 Feb 17. URL: https://www. who.int/docs/default-source/coronaviruse/situation-reports/20200217-sitrep-28-covid-19.pdf?sfvrsn=a19cf2ad 2 [accessed 2020-02-24]

21. Addie D, Schaap I, Nicolson L, Jarrett O. Persistence and transmission of natural type I feline coronavirus infection. J Gen Virol 2003 Oct;84(Pt 10):2735-2744. [doi: 10.1099/vir.0.19129-0] [Medline: 13679608]

22. Arbour N, Côté G, Lachance C, Tardieu M, Cashman NR, Talbot PJ. Acute and Persistent Infection of Human Neural Cell Lines by Human Coronavirus OC43. J. Virol 1999 Apr 01;73(4):3338-3350. [doi: 10.1128/jvi.73.4.3338-3350.1999]

23. Langmuir AD, Schoenbaum SC. The epidemiology of influenza. Hosp Pract 1976 Oct 06;11(10):49-56. [doi: 10.1080/21548331.1976.11707011] [Medline: 67988]

24. Thacker SB. The persistence of influenza A in human populations. Epidemiol Rev 1986;8(1):129-142. [doi: 10.1093/oxfordjournals.epirev.a036291] [Medline: 3533582]

25. Hope-Simpson RE, Golubev DB. A new concept of the epidemic process of influenza A virus. Epidemiol Infect 1987 Aug 19;99(1):5-54 [FREE Full text] [doi: 10.1017/s0950268800066851] [Medline: 3301379]

26. Hammond GW, Raddatz RL, Gelskey DE. Impact of atmospheric dispersion and transport of viral aerosols on the epidemiology of influenza. Rev Infect Dis 1989 May 01;11(3):494-497. [doi: 10.1093/clinids/11.3.494] [Medline: 2665004]

27. Tamerius J, Nelson MI, Zhou SZ, Viboud C, Miller MA, Alonso WJ. Global influenza seasonality: reconciling patterns across temperate and tropical regions. Environ Health Perspect 2011 Apr;119(4):439-445 [FREE Full text] [doi: 10.1289/ehp.1002383] [Medline: 21097384]

28. Lofgren E, Fefferman NH, Naumov YN, Gorski J, Naumova EN. Influenza Seasonality: Underlying Causes and Modeling Theories. JVI 2007 Jun 01;81(11):5429-5436. [doi: 10.1128/jvi.01680-06]

29. Tamerius JD, Shaman J, Alonso WJ, Alonso WJ, Bloom-Feshbach K, Uejio CK, et al. Environmental predictors of seasonal influenza epidemics across temperate and tropical climates. PLoS Pathog 2013 Mar 7;9(3):e1003194 [FREE Full text] [doi: 10.1371/journal.ppat.1003194] [Medline: 23505366]

30. Chan KH, Peiris JSM, Lam SY, Poon LLM, Yuen KY, Seto WH. The Effects of Temperature and Relative Humidity on the Viability of the SARS Coronavirus. Adv Virol 2011;2011:734690-734697 [FREE Full text] [doi: 10.1155/2011/734690] [Medline: 22312351]

31. National Meteorological Information Center. URL: https://data.cma.cn/en [accessed 2020-05-15]

32. Ministry of Ecology. URL: http://english.mee.gov.cn/ [accessed 2020-05-15]

33. China Meteorological Administration. URL: http://www.cma.gov.cn/en2014/ [accessed 2020-05-15]

34. Timeanddate.com. URL: https://www.timeanddate.com/ [accessed 2020-05-15]

35. Ministry of Health in China. URL: http://www.nhc.gov.cn/ [accessed 2020-12-08]

36. Ministry of Health Singapore. URL: https://www.moh.gov.sg/ [accessed 2020-12-08]

37. Hastie TJ. Generalized additive models for medical research. In: Hastie TJ, Tibshirani RJ, editors. Generalized Additive Models. Roca Baton, FL: Chapman \& Hall/CRC; 1995:187-196.

38. Katsouyanni K, Touloumi G, Samoli E, Gryparis A, Le Tertre A, Monopolis Y, et al. Confounding and effect modification in the short-term effects of ambient particles on total mortality: results from 29 European cities within the APHEA2 project. Epidemiology 2001 Sep;12(5):521-531. [doi: 10.1097/00001648-200109000-00011] [Medline: 11505171]

39. Peng RD, Dominici F, Louis TA. Model choice in time series studies of air pollution and mortality. J Royal Statistical Soc A 2006 Mar;169(2):179-203. [doi: 10.1111/j.1467-985x.2006.00410.x]

40. Kan H, London SJ, Chen G, Zhang Y, Song G, Zhao N, et al. Differentiating the effects of fine and coarse particles on daily mortality in Shanghai, China. Environ Int 2007 Apr;33(3):376-384 [FREE Full text] [doi: 10.1016/j.envint.2006.12.001] [Medline: 17229464$]$

41. Huang Y, Deng T, Yu S, Gu J, Huang C, Xiao G, et al. Effect of meteorological variables on the incidence of hand, foot, and mouth disease in children: a time-series analysis in Guangzhou, China. BMC Infect Dis 2013 Mar 13;13(1):134 [FREE Full text] [doi: 10.1186/1471-2334-13-134] [Medline: 23497074]

42. Huang C, Wang Y, Li X, Ren L, Zhao J, Hu Y, et al. Clinical features of patients infected with 2019 novel coronavirus in Wuhan, China. The Lancet 2020 Feb;395(10223):497-506 [FREE Full text] [doi: 10.1016/S0140-6736(20)30183-5] 
43. Dublineau A, Batéjat C, Pinon A, Burguière AM, Leclercq I, Manuguerra J. Persistence of the 2009 pandemic influenza A (H1N1) virus in water and on non-porous surface. PLoS One 2011 Nov 23;6(11):e28043 [FREE Full text] [doi: 10.1371/journal.pone.0028043] [Medline: 22132205]

44. Tan W, Hao F, McIntyre RS, Jiang L, Jiang X, Zhang L, et al. Is returning to work during the COVID-19 pandemic stressful? A study on immediate mental health status and psychoneuroimmunity prevention measures of Chinese workforce. Brain Behav Immun 2020 Jul;87:84-92 [FREE Full text] [doi: 10.1016/j.bbi.2020.04.055] [Medline: 32335200]

45. Xie X, Li Y, Chwang ATY, Ho PL, Seto WH. How far droplets can move in indoor environments--revisiting the Wells evaporation-falling curve. Indoor Air 2007 Jun;17(3):211-225. [doi: 10.1111/j.1600-0668.2007.00469.x] [Medline: 17542834$]$

46. Yang W, Marr LC. Dynamics of airborne influenza A viruses indoors and dependence on humidity. PLoS One 2011 Jun 24;6(6):e21481 [FREE Full text] [doi: 10.1371/journal.pone.0021481] [Medline: 21731764]

47. Schulman JL, Kilbourne ED. Airborne Transmission of Influenza Virus Infection in Mice. Nature 1962 Sep;195(4846):1129-1130. [doi: 10.1038/1951129a0]

48. To K, Lo AW. Exploring the pathogenesis of severe acute respiratory syndrome (SARS): the tissue distribution of the coronavirus (SARS-CoV) and its putative receptor, angiotensin-converting enzyme 2 (ACE2). J Pathol 2004 Jul 21;203(3):740-743 [FREE Full text] [doi: 10.1002/path.1597] [Medline: 15221932]

49. Yang W, Elankumaran S, Marr LC. Relationship between humidity and influenza A viability in droplets and implications for influenza's seasonality. PLoS One 2012 Oct 3;7(10):e46789 [FREE Full text] [doi: 10.1371/journal.pone.0046789] [Medline: 23056454]

50. Sajadi MM, Habibzadeh P, Vintzileos A, Shokouhi S, Miralles-Wilhelm F, Amoroso A. Temperature, Humidity and Latitude Analysis to Predict Potential Spread and Seasonality for COVID-19. SSRN 2020 Mar 09:3550308. [doi: 10.2139/ssrn.3550308] [Medline: $\underline{\text { 32714105] }}$

51. Feigin RD, San Joaquin VH, Haymond MW, Wyatt RG. Daily periodicity of susceptibility of mice to pneumococcal infection. Nature 1969 Oct 25;224(5217):379-380. [doi: 10.1038/224379a0] [Medline: 5343888]

52. Nelson RJ, Drazen DL. Melatonin mediates seasonal adjustments in immune function. Reprod. Nutr. Dev 1999;39(3):383-398. [doi: $10.1051 /$ rnd:19990310]
Abbreviations
AIC: Akaike information criterion
df: degrees of freedom
GAM: generalized additive modeling
MERS-CoV: Middle East respiratory syndrome coronavirus
PACF: partial autocorrelation function
RNA: ribonucleic acid
SARS-CoV: severe acute respiratory syndrome coronavirus
SARS: severe acute respiratory syndrome

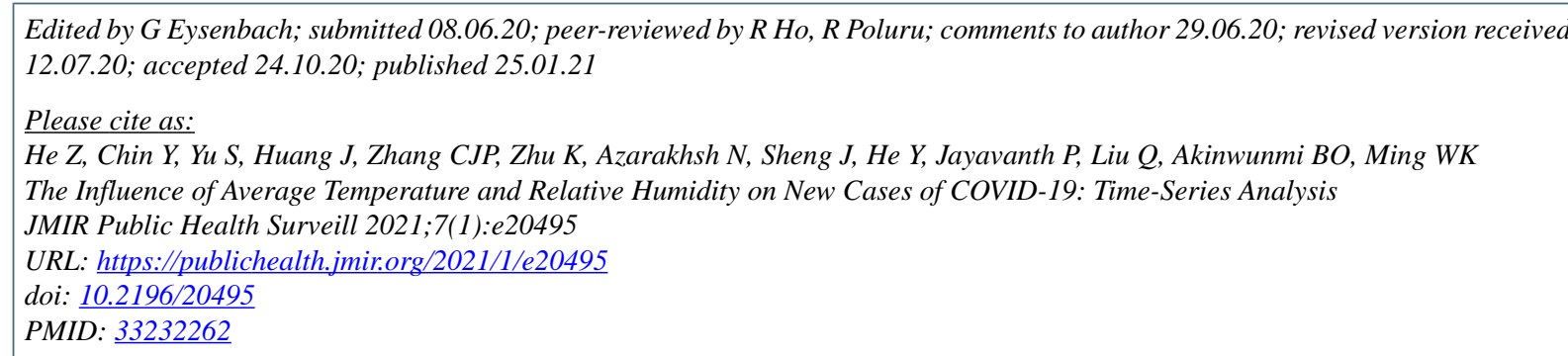

(CZonglin He, Yiqiao Chin, Shinning Yu, Jian Huang, Casper J P Zhang, Ke Zhu, Nima Azarakhsh, Jie Sheng, Yi He, Pallavi Jayavanth, Qian Liu, Babatunde O Akinwunmi, Wai-Kit Ming. Originally published in JMIR Public Health and Surveillance (http://publichealth.jmir.org), 25.01.2021. This is an open-access article distributed under the terms of the Creative Commons Attribution License (https://creativecommons.org/licenses/by/4.0/), which permits unrestricted use, distribution, and reproduction in any medium, provided the original work, first published in JMIR Public Health and Surveillance, is properly cited. The complete bibliographic information, a link to the original publication on http://publichealth.jmir.org, as well as this copyright and license information must be included. 